\title{
Article \\ Survival of Escherichia coli in Airborne and Settled Poultry Litter Particles
}

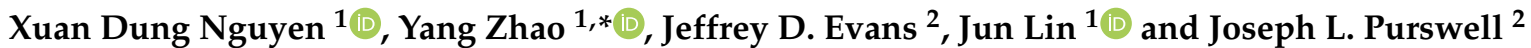 \\ 1 Department of Animal Science, The University of Tennessee, Knoxville, TN 37996, USA; \\ ndung@vols.utk.edu (X.D.N.); jlin6@utk.edu (J.L.) \\ 2 Poultry Research Unit, Agriculture Research Service, United States Department of Agriculture (USDA), \\ Mississippi State, MS 39762, USA; jeff.evans@usda.gov (J.D.E.); joseph.purswell@usda.gov (J.L.P.) \\ * Correspondence: yzhao@utk.edu; Tel.: +1-865-974-6466
}

check for updates

Citation: Nguyen, X.D.; Zhao, Y.; Evans, J.D.; Lin, J.; Purswell, J.L. Survival of Escherichia coli in Airborne and Settled Poultry Litter Particles. Animals 2022, 12, 284. https://doi.org/10.3390/ ani12030284

Academic Editor: Colin Scanes

Received: 23 December 2021

Accepted: 19 January 2022

Published: 24 January 2022

Publisher's Note: MDPI stays neutral with regard to jurisdictional claims in published maps and institutional affiliations.

Copyright: () 2022 by the authors Licensee MDPI, Basel, Switzerland. This article is an open access article distributed under the terms and conditions of the Creative Commons Attribution (CC BY) license (https:// creativecommons.org/licenses/by/ $4.0 /)$.
Simple Summary: Airborne transmission is recognized as an important mechanism of disease spreading in livestock and poultry production, yet is far from being fully understood. Evaluating the impact of airborne transmission requires information of the microbial survivability. We determined the survivability of the E. coli-a common microbial species found in poultry environment-in airborne particles, settled dust, and poultry litter under laboratory environmental conditions. The poultry litter which contained mainly manure mixed with fresh wood shavings was collected from a commercial farm. Results of the study showed that the half-life time of airborne E. coli was $5.7 \pm 1.2 \mathrm{~min}$. The half-life time of $E$. coli in poultry litter and settled particles was $15.9 \pm 1.3 \mathrm{~h}$ and $9.6 \pm 1.6 \mathrm{~h}$, respectively. The findings of this study will help better estimate the impact of airborne transmission of $E$. coli in poultry production.

\begin{abstract}
Airborne Escherichia coli (E. coli) in the poultry environment can migrate inside and outside houses through air movement. The airborne E. coli, after settling on surfaces, could be re-aerosolized or picked up by vectors (e.g., caretakers, rodents, transport trucks) for further transmission. To assess the impacts of airborne E. coli transmission among poultry farms, understanding the survivability of the bacteria is necessary. The objective of this study is to determine the survivability of airborne E. coli, settled E. coli, and E. coli in poultry litter under laboratory environmental conditions $\left(22-28{ }^{\circ} \mathrm{C}\right.$ with relative humidity of 54-63\%). To determine the survivability of airborne E. coli, an AGI-30 bioaerosol sampler (AGI-30) was used to collect the E. coli at 0 and $20 \mathrm{~min}$ after the aerosolization. The half-life time of airborne $E$. coli was then determined by comparing the number of colony-forming units (CFUs) of the two samplings. To determine the survivability of settled E. coli, four sterile Petri dishes were placed on the chamber floor right after the aerosolization to collect settled E. coli. The Petri dishes were then divided into two groups, with each group being quantified for culturable $E$. coli concentrations and dust particle weight at $24-\mathrm{h}$ intervals. The survivability of settled E. coli was then determined by comparing the number of viable E. coli per milligram settled dust collected in the Petri dishes in the two groups. The survivability of E. coli in the poultry litter sample (for aerosolization) was also determined. Results show that the half-life time of airborne E. coli was $5.7 \pm 1.2 \mathrm{~min}$. The survivability of $E$. coli in poultry litter and settled $E$. coli were much longer with the half-life time of $15.9 \pm 1.3 \mathrm{~h}$ and $9.6 \pm 1.6 \mathrm{~h}$, respectively. In addition, the size distribution of airborne E. coli attached to dust particles and the size distribution of airborne dust particles were measured by using an Andersen impactor and a dust concentration monitor (DustTrak). Results show that most airborne E. coli $(98.89 \%$ of total E. coli) were carried by the dust particles with aerodynamic diameter larger than $2.1 \mu \mathrm{m}$. The findings of this study may help better understand the fate of $E$. coli transmitted through the air and settled on surfaces and evaluate the impact of airborne transmission in poultry production.
\end{abstract}

Keywords: airborne E. coli; settled E. coli; survivability; airborne transmission; poultry 


\section{Introduction}

The United States of America (USA) is one of the leading countries in poultry production. Poultry products originating in the USA primarily consist of meat from broilers and turkeys and eggs from layers. According to the USDA report [1], the combined value of production from these products in 2020 exceeded USD 35 billion. These products provide important and affordable sources of dietary protein to the domestic population. In addition, approximately $18 \%$ of the USA poultry products are exported and poultry production in the USA was estimated to provide over 1 million jobs. However, the outbreak of infectious diseases is one of the biggest challenges for the poultry industry. For example, the Highly Pathogenic Avian Influenza (HPAI) outbreaks in the USA in 2015 resulted in losses of over 50 million birds and 3.3 billion dollars [2].

Escherichia coli (E. coli) is a member of the Enterobacteriaceae family and is commonly associated with the intestinal tract of warm-blooded animals and the environment in which these animals reside. In poultry, E. coli primarily inhabits the lower gastrointestinal tract as an indicator for the poultry environmental quality and exists there as an important commensal species. Typically, E. coli are harmless, but some E. coli strains may be pathogenic in nature and their virulence may lead to losses in the poultry industry. Pathogenic E. coli strains in poultry are commonly referred to as avian pathogenic E. coli (APEC) [3]. The APEC causes the systemic disease colibacillosis in broilers. The severity of APEC disease depends on the health status of the host, virulence characteristics of the E. coli strain, and other predisposing factors such as stress. Approximately $30 \%$ of broiler flocks in the U.S are infected by subclinical colibacillosis [4].

E. coli can be abundant in poultry house with concentrations up to $4 \log _{10}$ CFU m $\mathrm{m}^{-3}$ in the air [5], $3 \log _{10} \mathrm{CFU} \mathrm{g}{ }^{-1}$ in feeds [6], and $7 \log _{10} \mathrm{CFU} \mathrm{g} \mathrm{g}^{-1}$ in poultry litter [7]. To reduce the economic losses caused by E. coli, antibiotics, such as tetracyclines and trimethoprim sulfamethoxazole, have been widely utilized in poultry feed [8]. However, the widespread use of antibiotics can cause the emergence and re-emergence of antibiotic resistant bacterial strains. Thus, the use of antibiotics has been limited and many bacteria, including E. coli, have reemerged as significant threats to poultry production. Some alternatives were developed to reduce $E$. coli contamination of the farm microclimate such as probiotics [9] and UV lights [10]. These methods do not rely on the use of antibiotics and are relatively effective in reducing microbial contamination in poultry houses. However, these studies have not mentioned the effectiveness of reducing airborne bacteria which attach to dust particles. Therefore, further studies on airborne E. coli attached to dust particles such as their survivability or size distribution which directly affects the effectiveness of the methods are needed to investigate.

The litter is a major reservoir of microorganisms in the poultry environment [11]. The dry matter contents can be about $70-80 \%$ of litter mass and it can contain abundant biological organisms and compounds that can affect the quality of the poultry environment [12]. Dust particles are aerosolized because of bird activity, as such, the poultry environment is highly dusty.

Air in the poultry houses may contain abundant microorganisms such as E. coli [13]. E. coli from manure first deposit into poultry litter and are then aerosolized through bird activities [14]. Ventilation systems can drive their migration across a poultry house or even from barn to barn. Airborne E. coli were shown to account for $2-6 \%$ of the total airborne bacteria in poultry houses [5]. With the high concentration of E. coli and the possibility of barn-to-barn transmission, the airborne E. coli can harm the entire wide range of environment outside the poultry houses, and they can deposit on surfaces near the poultry houses. The barn-to-barn airborne transmission of avian influenza was investigated in a study conducted in 2019 [15]. The probability of airborne infection is affected by several factors including farm type, flock size, and distance of transmission where the survivability of the pathogen is among the key factors for the modeling accuracy. Moreover, the survivability of $E$. coli on stainless steel under refrigeration conditions and room temperature was reported to exceed 28 days [16]. Therefore, it is also possible that E. coli 
can persist for a long time on various surfaces in the poultry production environment. With such a long survival period on the surface, they can spread to larger areas through vectors. These all raise the question of how long the airborne $E$. coli, carried by poultry litter particles, can survive in the air and on the physical surfaces when settled.

To determine the survivability of airborne and settled E. coli in laboratory, a proper aerosolization method that may mimic the fate of E. coli in the commercial poultry production environment is required. The wet aerosolization method such as nebulization was widely used to study the survivability of airborne E. coli [17]. However, the airborne E. coli in poultry houses are aerosolized from dried litter by bird activities, such as dust bathing [14]. So, the results of the study based on wet aerosolization cannot apply to the actual situation in the poultry house. In addition, the survivability of settled E. coli after going through the dry aerosolization process has never been investigated. Therefore, a study to determine the survivability of airborne E. coli and settled E. coli after being aerosolized based on dry aerosolization method needs to be done.

Size distribution of airborne $E$. coli attached to dust particles could affect the survivability of airborne E. coli. In a study conducted by Zuo et al. [18], the authors mentioned that carrier particle size had a significant effect on the survivability of airborne viruses. Lighthart et al. [19] also reported that test bacterial survivability increased directly with droplet size. However, most of the studies used droplets as aerosol particles to carry bacteria and viruses. The dry dust particles may yield different results compared to droplets. So, the size distribution of airborne E. coli attached to dry dust particles also needed to be investigated.

This study aimed to investigate the survivability of airborne and settled E. coli via dry aerosolization under room thermal conditions. In addition, the survivability of $E$. coli in poultry litter was also investigated as a reference parameter.

\section{Materials and Methods}

To investigate the survivability of the airborne E. coli and the settled E. coli, experiments were run in a test chamber in a Biosafety Level 2 (BSL-2) laboratory. The survivability test of E. coli in poultry litter was conducted in Biosafety Level 1 (BSL-1) laboratory. Both laboratories are located at the Animal Science Department, University of Tennessee, Knoxville, TN 37996, USA.

\subsection{Microorganism and System Descriptions}

\subsubsection{Preparation of E. coli Solution}

The E. coli strain used in this study was Escherichia coli GFP (ATCC ${ }^{\circledR} 25922 \mathrm{GFP}^{\mathrm{TM}}$ ) which was purchased from American Type Culture Collection (ATCC, Manassas, VA, USA). E. coli strain was cultured at $37^{\circ} \mathrm{C}, 150 \mathrm{rpm}$ for $24 \mathrm{~h}$ in ATCC ${ }^{\circledR}$ Medium 2855 (Tryptic Soy Broth 'TSB' with $100 \mathrm{mcg} \mathrm{mL}^{-1}$ Ampicillin and Tryptic Soy Agar 'TSA'). The bacterial concentrations of E. coli in the solution after $24 \mathrm{~h}$ were from 8 to $9 \log _{10}$ colony-forming units $\left(\log _{10} \mathrm{CFU}\right) \mathrm{mL}^{-1}$.

\subsubsection{Litter Preparation}

Litter from the commercial broiler farm was first collected and stored in a container. It was then brought back to the BSL-1 laboratory to analyze the dry matter content. After that, the litter was autoclaved at $121^{\circ} \mathrm{C}$ in $20 \mathrm{~min}$ and divided into identical-size aluminum boxes with the amount of $6 \mathrm{~kg}$ per box. The autoclaved poultry litter was used as a source of organic matter to simulate the biological conditions in poultry environment [20]. The sterilization was confirmed to demonstrate a state of freedom from microbial contamination. The boxes were sealed by aluminum foils and covered by plastic caps to avoid contamination. They were stored in a $4{ }^{\circ} \mathrm{C}$ fridge until being used.

It was important to prepare litter so that the bacteria were evenly distributed. To do that, $240 \mathrm{~g}$ of litter needed for the survivability test of airborne E. coli and settled E. coli experiment were equally distributed into 40 ceramic cups (6 $\mathrm{g}$ litter per cup). The amount 
of airborne dust that can be generated using a mixer was determined in a previous experiment [21], and the results showed that $240 \mathrm{~g}$ of litter would produce dust concentrations ranging from 0.9 to $1.1 \mathrm{mg} \mathrm{m}^{-3}$ which was within a typical range of dust concentration in commercial poultry farm [22]. To prepare litter inoculated with E. coli, litter in each of the 40 cups was mixed with $6 \mathrm{~mL}$ of $E$. coli solution. The $6 \mathrm{~mL}$ bacteria solution was sprayed evenly onto the litter in each cup. In the meantime, an aluminum spoon was used to gently mix the litter and E. coli solution. The mixtures then went through a process of drying at $22{ }^{\circ} \mathrm{C}$ and $52-67 \%$ relative humidity (RH) for $48 \mathrm{~h}$ until the dry matter content (DMC) of the mixture reached about $70 \%$. The $E$. coli concentration in each cup was approximately $4 \log _{10} \mathrm{CFU} \mathrm{mg}{ }^{-1}$ litter after the drying process. The litter containing E. coli was then transferred from 40 ceramic cups to a metal bowl of the mixer for aerosolization. In the bowl, the litter was gently mixed up again before aerosolization.

\subsubsection{Test Chamber}

Aerosolization was performed in an acrylic chamber. This chamber (2100 series, Cleatech, Orange, CA, USA) was a non-vacuum unit with two internal access doors with stainless steel frame, and a removable fully gasketed back wall. The dimension of the test chamber was $1.5 \mathrm{~mL} \times 0.6 \mathrm{~mW} \times 0.6 \mathrm{mH}$. The chamber was well sealed to prevent dust-laden particles from spilling out. It was also equipped with a temperature and $\mathrm{RH}$ sensor for continuously monitoring the inside thermal environment.

In the settled E. coli experiment, the chamber was modified to create a highly dusty environment in order to collect adequate settle dust for analysis. Initial results showed that the aerosolization space of the entire chamber was too large which led to the low concentration of airborne E. coli and dust particles. Thus, the chamber was modified by halving the aerosolization space using a partition acrylic film. The aerosolization space after modification was $0.75 \mathrm{~mL} \times 0.6 \mathrm{~mW} \times 0.6 \mathrm{mH}$.

\subsubsection{Aerosolization System}

A stand mixer (model DCSM350GBRD02, New York, NY, USA) was used for dry aerosolization of airborne E. coli in this study. The dimension of the mixer was $0.3 \mathrm{~mL} \times 0.2 \mathrm{~mW} \times 0.3 \mathrm{mH}$ with a $3.3 \mathrm{~L}$ stainless steel bowl. They operated at the highest speed to ensure the bacteria concentration in the air was high enough. A stir fan was also used to distribute the airborne E. coli in the chamber evenly.

\subsubsection{Dust Concentration Monitor}

To monitor the dust concentration throughout the experiment, a dust concentration monitor (DustTrak DRX aerosol monitor 8533, TSI Inc., Shoreview, MN, USA) was used to provide data on the mass concentration of dust particles with different sizes. DustTrak was capable of measuring dust particles of PM 1, PM 2.5, PM 4.7, and PM 10. In this study, the dust concentration and particle size were recorded, and the results indicated that the particle concentration was relatively stable between experimental events.

\subsubsection{Air Samplers}

To evaluate the survivability of the airborne E. coli, the AGI-30 impinger (AGI-30) was used to collect $E$. coli-laden dust particles in a test chamber in a BSL-2 laboratory. The AGI-30 operates at $12.5 \mathrm{~L} \mathrm{~min}^{-1}$. The airborne compounds were sucked through a fine nozzle in which the particles were accelerated and then impacted directly into the $20 \mathrm{~mL}$ TSB. The AGI-30 was proven to have the highest performance among three commonly used samplers (Andersen impactor, AGI-30 impinger, and BOBCAT ACD-200) for collecting airborne E. coli [21]. 


\subsection{Experimental Design and Procedures}

2.2.1. Bacterial Size Distribution and Viable E. coli Recovering in the Airborne E. coli Survivability Test

An Andersen impactor was used to monitor the bacterial size distribution. The Andersen impactor is designed as an aerodynamic classifying system for airborne particles. It operates at $28.3 \mathrm{~L} \mathrm{~min}^{-1}$. Its six stages are designed to sort dust particles with different sizes of $>7 \mu \mathrm{m}, 4.7-7 \mu \mathrm{m}, 3.3-4.7 \mu \mathrm{m}, 2.1-3.3 \mu \mathrm{m}, 1.1-2.1 \mu \mathrm{m}, 0.65-1.1 \mu \mathrm{m}$, corresponding to stage 1 to stage 6 . The dust particles carrying E. coli, after being aerosolized, were sucked in the intake on top of the Andersen impactor; then, the particles continuously went through 6 stages. For each stage, dust particles with sizes corresponding to each stage were collected on TSA agar plates.

In the process of sampling with the Andersen impactor, the stages of the sampler were often overloaded due to the excessive number of bacteria collected in each stage. Therefore, counting bacteria on agar plates directly was not possible. To overcome this problem, the agar plate washing method was applied. Bacteria, after being collected on agar plates, were immediately taken to the laboratory for analysis. Each agar plate was rinsed with $2 \mathrm{~mL}$ of TSB solution with the aid of a glass spreader, and then $1 \mathrm{~mL}$ of solution was collected by pipette. The $1 \mathrm{~mL}$ of this solution went through a traditional serial dilution process to determine the total E. coli in the solution. The agar plates, after washing, were also placed in an incubator letting the remaining E. coli on the plate grow. During the air sampling process, the agar plates in the Andersen impactor were dried by air flow in the sampler. Thus, the remaining $1 \mathrm{~mL}$ of solution in the washing process was mostly reabsorbed into the agar plates. However, to make sure that there is no residual solution that could affect the test results, the agar plates that have been washed instead of being turned upside down (due to traditional culture process) will be left right side up. The total E. coli on each stage was the combination of total E. coli collected from washing and total E. coli remaining on agar plates.

\subsubsection{Dry Matter Content Measurement}

The moisture content is one variable affecting the survivability of bacteria [23]. The dry matter content (DMC), which is the inverse term of moisture content, was measured over time in the experiment. The DMC measurement of poultry litter is the ratio of the litter mass before and after the litter is completely dried. To determine DMC, the process was divided into two stages. First, the litter mass $\left(\mathrm{m}_{1}\right)$ was weighted before going through a 48-h drying process until the litter mass was totally dried. After being dried at $105^{\circ} \mathrm{C}$, the litter mass $\left(\mathrm{m}_{2}\right)$ was weighted again. The DMC was then calculated by the litter mass $\mathrm{m}_{2}$ divided by the litter mass $\mathrm{m}_{1}$.

\subsubsection{Sample Collection for Airborne E. coli}

Two hundred and forty grams (240 g) of litter which contained $\sim 4 \log _{10} \mathrm{CFU} \mathrm{mg}{ }^{-1}$ litter of E. coli were prepared and placed in the mixer. The mixer was placed in the center of the chamber to help evenly distribute the dust particles carrying E. coli. The mixer was fixed to the chamber surface by means of suckers, preventing it from moving during the running process. The stir fan was placed at the corner of the chamber to aid in distributing airborne particles. The AGI-30 was placed near the steel bowl of the mixer.

Each test lasted a total of $50 \mathrm{~min}$. The first $20 \mathrm{~min}$ of the test was the aerosolization process of airborne E. coli using the mixer and stir fan. After the 20-min aerosolization, airborne E. coli was collected using the AGI-30 for $10 \mathrm{~min}$ and the dust concentration was determined using DustTrak. The second sampling of airborne E. coli and dust followed the same protocol but was performed $10 \mathrm{~min}$ after the first sampling. This test procedure was repeated 7 times. 


\subsubsection{Sample Collection for Settled E. coli}

Two mixers were used for aerosolization. Two hundred and forty grams $(240 \mathrm{~g})$ of litter which contained about $4 \log _{10} \mathrm{CFU} \mathrm{mg}{ }^{-1}$ litter of $E$. coli were mixed gently and divided into two parts with $120 \mathrm{~g}$ for each mixer. The stir fan was operated during the aerosolization to improve the distribution of airborne E. coli in the chamber. Four Petri dishes were placed on both sides of the mixers to collect particles settled from the air. To avoid the position confounding effect, the Petri dishes were arranged randomly in a total of 4 experiment events. Each event started with 15 min aerosolization. After the aerosolization, the four Petri dishes were covered with caps and sealed by parafilm. Two Petri dishes were immediately analyzed to quantify viable $E$. coli via traditional culture technique. The remaining two Petri dishes were left at laboratory temperature at $20^{\circ} \mathrm{C}$, $\mathrm{RH}$ at $60 \%$ for $24 \mathrm{~h}$. After that, they were quantified for viable $E$. coli by the same culture technique. The weight of each Petri dish was determined before and after aerosolization to determine the settle dust weight. The airborne dust concentration during the mixer running time was also monitored by DustTrak.

\subsubsection{Viable E. coli Counting for E. coli Survivability Test in Poultry Litter}

Fifteen (15) ceramic cups, each with six grams (6 g) of poultry litter, were prepared to determine the survivability of E. coli in the litter. The six grams of poultry litter were spread in each ceramic cup so that the thickness of the litter was uniform and without large lumps. Then, $6 \mathrm{~mL}$ of $E$. coli solution was added to the litter by using a pipette. The solution was sprayed onto the litter, ensuring that the bacterial fluid was distributed as evenly as possible. After that, the mixture of litter and bacterial solution were mixed gently by using an aluminum spoon. The cup was then placed in the BSL-1 under laboratory conditions. The viable $E$. coli in the litter were determined at $0,12,24,48$, and $72 \mathrm{~h}$ after litter samples were prepared in the ceramic cups. At each time point, three cups of samples were used. In addition, two cups of litter added with the TSB solution instead of the bacteria solution were used as a control for E. coli analysis and DMC measurement.

To determine the viable $E$. coli counts, TSB was added in each cup so that the total volume of the mixture reached $15 \mathrm{~mL}$. The mixture was mixed evenly. Then, $0.1 \mathrm{~mL}$ of the solution (litter-bacteria mixture mixed with TSB) was taken out and transferred to $0.9 \mathrm{~mL}$ of TSB. After that, the solution went through a serial dilution process to determine the counts of viable E. coli. By doing back-calculation, the bacterial concentration in poultry litter was calculated.

\subsubsection{Determining E. coli Concentration in Poultry Litter}

To determine the viable $E$. coli, the $E$. coli concentrations were calculated in logarithm colony-forming units per gram $\left(\log _{10} \mathrm{CFU} \mathrm{mg}{ }^{-1}\right)$ using Equation (1).

$$
\mathrm{C}=\log _{10}\left(\frac{\mathrm{N} \times 10^{\mathrm{n}}}{\mathrm{V}_{\mathrm{p}}} \times \mathrm{V}_{\mathrm{s}} \times \frac{1}{\mathrm{~m}_{\mathrm{a}}}\right),
$$

where $\mathrm{C}=$ the bacteria concentration, $\log _{10} \mathrm{CFU} \mathrm{mg}{ }^{-1} ; \mathrm{N}=$ the number of colonies on a countable plate (30 to 300 colonies); $\mathrm{n}=$ serial dilution factor ( $\mathrm{n}=0$ for undiluted sample, $\mathrm{n}=1$ for 10 -fold diluted sample, etc.); $\mathrm{V}_{\mathrm{P}}=$ the sample volume plated, $\mathrm{mL}\left(\mathrm{V}_{\mathrm{P}}=0.1 \mathrm{~mL}\right.$ in this study); $\mathrm{V}_{\mathrm{s}}=$ the total volume of the original liquid sample, $\mathrm{mL} ; \mathrm{m}_{\mathrm{a}}=$ the total poultry litter weight in each ceramic cup at the test time, mg.

\subsubsection{Determining Airborne E. coli Concentration}

Each air sample collected by AGI-30 in liquid form (in TSB medium) was used to quantify viable $E$. coli via traditional culture techniques. After vortexing for $5 \mathrm{~s}$, a $0.1 \mathrm{~mL}$ subsample, after going through the serially diluted (1:10) process, was plated onto TSA agar plates. In each experimental event, the subsample was uniformly repeated 3 times to ensure the accuracy of the experiment. The plates were aerobically incubated at $37^{\circ} \mathrm{C}$ 
for $24 \mathrm{~h}$. The visible E. coli colonies formed on plates (30 to 300 colonies) were determined. Based on the culture results and the sampled air volume, airborne $E$. coli concentrations were calculated in logarithm colony-forming units per cubic meter $\left(\log _{10} \mathrm{CFU} \mathrm{m} \mathrm{m}^{-3}\right)$ using Equation (1). The parameter $\mathrm{m}_{\mathrm{a}}$ converted to $\mathrm{V}_{\mathrm{a}}$ which is the total air volume sampled using the bioaerosol samplers, $\mathrm{m}^{3}$.

\subsubsection{Determining Settled E. coli Concentration}

Each settled sample on an empty Petri dish was used to quantify viable settled E. coli. After adding $10 \mathrm{~mL}$ of TSB medium (the culture medium) in each Petri dish, the Petri dish was gently shaken to wash the Petri dish surface and draw settled E. coli into TSB solution. After that, $0.1 \mathrm{~mL}$ of the solution containing E. coli was taken by using a pipette and went through a serial dilution process to count viable E. coli. Then, the viable E. coli was determined as the Equation (1). The parameter $\mathrm{m}_{\mathrm{a}}$ was the mass of settled dust collected in each dish in each experiment, $\mathrm{mg}$.

\subsection{Calculation of Half-Life Time}

The half-life time is the time interval needed for bacteria to decrease by half [24]. The bacterial concentrations throughout the experiments would be homogenized and normalized to the dust concentration $\left(\mathrm{CFU} \mathrm{mg} \mathrm{mg}^{-1}\right)$. In the survivability of the airborne $E$. coli test, the airborne E. coli concentration was calculated based on airborne E. coli concentration collected in the air $\left(\mathrm{CFU} \mathrm{m}{ }^{-3}\right)$ divided by total dust concentration $\left(\mathrm{mg} \mathrm{m}^{-3}\right)$. In the survivability of the settled E. coli test, the settled E. coli concentration was calculated based on the settled E. coli concentration collected on each Petri dish (CFU mg ${ }^{-1}$ ). The half-life time, then, was calculated by the following Equation (2).

$$
\mathrm{t}_{1 / 2}=\frac{\log _{10} 2 \times \mathrm{T}}{\log _{10}\left(\mathrm{C}_{\text {viable bacteria }} / \mathrm{C}_{\text {viable bacteria }}^{\prime}\right)},
$$

where $t_{1 / 2}$ : half-life time ( $\min$ or $\mathrm{h}$ ); $\mathrm{T}=20(\mathrm{~min})$ for airborne $E$. coli and $24(\mathrm{~h})$ for settled E. coli test; $\mathrm{C}_{\text {viable bacteria }}$ E. coli concentration for the first sampling event, $\mathrm{CFU} \mathrm{mg}{ }^{-1}$;

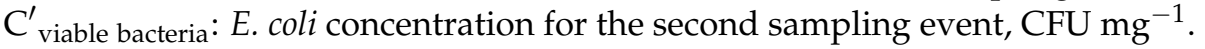

Linear simple regression was performed to calculate the half-life time of E. coli. The half-life time of E. coli in poultry litter was calculated based on the E. coli death over time by the linear Equation (3) [25]:

$$
\mathrm{t}_{1 / 2}=\frac{\text { constant }-\log _{10}\left(\frac{\mathrm{C}_{\text {viable bacteria }}}{2}\right)}{\mathrm{k}},
$$

where $\mathrm{C}_{\text {viable bacteria }}$ : the $E$. coli concentration at $0 \mathrm{~h}, \mathrm{CFU} \mathrm{mg}{ }^{-1}$; constant: intercept of the linear regression model, $\log _{10} \mathrm{CFU} \mathrm{mg}{ }^{-1}$; $\mathrm{k}$ : the death rate, $\left[\log _{10} \mathrm{CFU} \mathrm{\textrm {mg } ^ { - 1 }}\right] \mathrm{h}^{-1}$; and $\mathrm{t}_{1 / 2}$ : half-life time, $\mathrm{h}$.

\subsection{Statistical Analysis}

Means and standard deviations for all experiments were calculated by using Rstudio (Rstudio, open-source license, Rstudio, Boston, MA, USA). Total 7 replicates for airborne E. coli experiment and 4 replicates for settled E. coli yielded decent statical analysis for calculating the half-life time. The conditions such as dust concentration among experiments were tested with the T-test to make sure there was no significant difference in terms of experimental conditions. The $t$-test significance level was $0.05(p<0.05)$. For the survivability of $E$. coli in poultry litter, at every time point, the concentration of E. coli in poultry litter was tested repeatedly 3 times for reliable viable E. coli data.

The half-life time of airborne E. coli, settled E. coli and E. coli in poultry litter were compared, and the differences between the survivability of E. coli under different conditions were tested by using a $t$-test run on Rstudio. The $t$-test was used to determine if the means of 
three sets of data (E. coli in poultry litter, airborne E. coli, and settled E. coli) are significantly different from each other. The $t$-test significance level was $0.05(p<0.05)$.

\section{Results}

\subsection{Conditions for E. coli Survivability Test}

Table 1 shows the litter DMC, initial litter E. coli concentration and environmental conditions during the experiments for determining survivability of airborne E. coli, settled E. coli and the E. coli in poultry litter. The DMC of litter, E. coli concentration and RH in the litter were kept stable throughout the experiments. In the test for settled E. coli survivability, instead of using one mixer, two mixers were used. Therefore, the heat generated in the two mixers caused the temperature in the test for settled E. coli survivability to be slightly higher than the two other tests.

Table 1. Conditions (Mean $\pm \mathrm{SD}$ ) for the E. coli in survivability test.

\begin{tabular}{|c|c|c|c|}
\hline $\begin{array}{l}\text { E. coli Concentration and } \\
\text { Environmental Conditions }\end{array}$ & $\begin{array}{l}\text { Test for Airborne } \\
\text { E. coli Survivability }\end{array}$ & $\begin{array}{c}\text { Test for Settled } \\
\text { E. coli Survivability }\end{array}$ & $\begin{array}{c}\text { Test for E. coli in Poultry Litter } \\
\text { Survivability }\end{array}$ \\
\hline $\mathrm{DMC}^{1}$ of litter $(\%)$ & $71 \pm 5$ & $72 \pm 1$ & -2 \\
\hline E. coli concentration in litter $\left(\log _{10} \mathrm{CFU} \mathrm{mg} \mathrm{m}^{-1}\right)$ & $4.4 \pm 0.6$ & $4.0 \pm 0.5$ & -2 \\
\hline Relative humidity $(\%)$ & $54 \pm 5$ & $63 \pm 7$ & $36 \pm 4$ \\
\hline Temperature $\left({ }^{\circ} \mathrm{C}\right)$ & $22.1 \pm 1.4$ & $27.7 \pm 5.1$ & $20.5 \pm 0.3$ \\
\hline
\end{tabular}

${ }^{1}$ Dry matter content, ${ }^{2}$ DMC and bacteria concentration varied over $72 \mathrm{~h}$.

\subsection{Size Distribution of E. coli and Dust for the Airborne E. coli Survivability Test}

The size distribution of airborne E. coli attached to dust particles and the size distribution of airborne dust particles were tested. The size distribution of airborne E. coli attached to dust particles during the 20-min aerosolization process is shown in Figure 1 . The most $E$. coli were found in the particles larger than $7 \mu \mathrm{m}$ with a percentage of $47.58 \%$. The second large portion of $E$. coli was those attached to particles in the range of 4.7 to $7 \mu \mathrm{m}$, accounting for $27.34 \%$. E. coli attached to dust particles in the ranges of 3.3-4.7 $\mu \mathrm{m}$ and $2.1-3.3 \mu \mathrm{m}$ accounted for $14.05 \%$ and $9.92 \%$ of the total culturable E. coli, respectively. The least E. coli were found in particles smaller than $2.1 \mu \mathrm{m}$ which accounted for $1.11 \%$ of the total culturable E. coli.

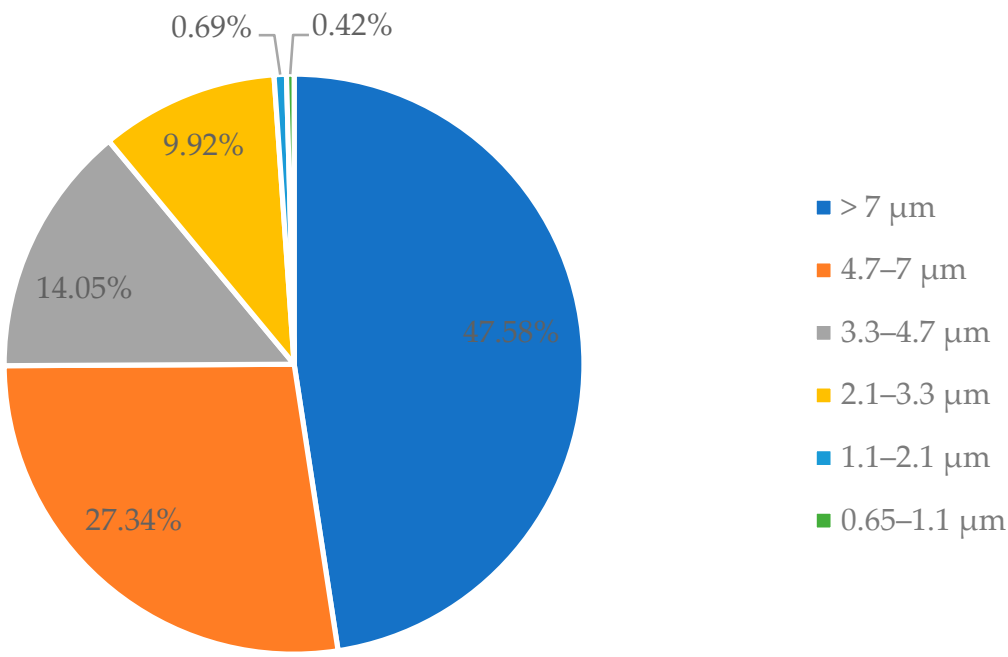

Figure 1. Size distribution of the airborne E. coli attached to dust particles in the airborne E. coli survivability test measured by an Andersen impactor.

The size distribution of airborne dust particles during the 20-min aerosolization process was monitored by the DustTrak and shown in Table 2. Most dust particles have the size smaller than $1 \mu \mathrm{m}$ with a concentration of $0.678 \pm 0.108 \mathrm{mg} \mathrm{m}^{-3}$. The rest 
of the dust particles have size range of 1.0-2.5 $\mu \mathrm{m}, 2.5-4.7 \mu \mathrm{m}, 4.7-10.0 \mu \mathrm{m}$ and larger than $10.0 \mu \mathrm{m}$, with a concentration of $0.014 \pm 0.001 \mathrm{mg} \mathrm{m}^{-3}, 0.016 \pm 0.005 \mathrm{mg} \mathrm{m}^{-3}$, $0.235 \pm 0.042 \mathrm{mg} \mathrm{m}^{-3}$ and $0.232 \pm 0.032 \mathrm{mg} \mathrm{m}^{-3}$, respectively. The total dust concentration was about $1.176 \pm 0.120 \mathrm{mg} \mathrm{m}^{-3}$. As shown in Table 2 and Figure 1, although most dust particles were smaller than $1 \mu \mathrm{m}$, the size distribution of bacteria attached to dust particles was mainly larger than $2.1 \mu \mathrm{m}$, accounting for $98.89 \%$. This indicates that when it comes to airborne E. coli, most are attached to dust particles with the size larger than $2.1 \mu \mathrm{m}$.

Table 2. Dust size distribution (Means $\pm \mathrm{SD}$ ) in the airborne E. coli survivability test.

\begin{tabular}{|c|c|c|c|c|c|}
\hline $\begin{array}{c}<1.0 \mu \mathrm{m} \\
\left(\mathrm{mg} \mathrm{m}^{-3}\right)\end{array}$ & $\begin{array}{c}1.0-2.5 \mu \mathrm{m} \\
\left(\mathrm{mg} \mathrm{m}^{-3}\right)\end{array}$ & $\begin{array}{c}2.5-4.7 \mu \mathrm{m} \\
\left(\mathrm{mg} \mathrm{m}^{-3}\right)\end{array}$ & $\begin{array}{c}4.7-10.0 \mu \mathrm{m} \\
\left(\mathrm{mg} \mathrm{m}^{-3}\right)\end{array}$ & $\begin{array}{l}>10.0 \mu \mathrm{m} \\
\left(\mathrm{mg} \mathrm{m}^{-3}\right)\end{array}$ & $\begin{array}{c}\text { Total } \\
\left(\mathrm{mg} \mathrm{m}^{-3}\right)\end{array}$ \\
\hline $\begin{array}{c}0.678 \pm 0.108 \\
\quad(57.60 \%)^{1}\end{array}$ & $\begin{array}{c}0.014 \pm 0.001 \\
(1.20 \%)^{1}\end{array}$ & $\begin{array}{c}0.016 \pm 0.005 \\
(1.40 \%)^{1}\end{array}$ & $\begin{array}{c}0.235 \pm 0.042 \\
(20.00 \%)^{1}\end{array}$ & $\begin{array}{c}0.232 \pm 0.032 \\
(19.80 \%)^{1}\end{array}$ & $\begin{array}{c}1.176 \pm 0.120 \\
(100.00 \%)^{1}\end{array}$ \\
\hline
\end{tabular}

${ }^{1}$ Percentage of the total for each size range.

\subsection{E. coli Survivability in Poultry Litter}

The survivability of E. coli in poultry litter was determined in a 72-h test under laboratory conditions and delineated in Figure 2. The temperature and $\mathrm{RH}$ remained stable throughout the test at $20.5 \pm 0.3{ }^{\circ} \mathrm{C}$ and $36 \pm 4 \%$. The DMC of litter (containing E. coli) changed throughout the test and was presented in Figure 2. The E. coli concentration decreased from $4.5 \log _{10} \mathrm{CFU} \mathrm{mg}{ }^{-1}$ to $2.4 \log _{10} \mathrm{CFU} \mathrm{mg}-1$ over $72 \mathrm{~h}$. The DMC increased from $38 \%$ to $82 \%$ due to moisture evaporation. The half-life time of $E$. coli in poultry litter calculated based on the linear regression was $15.9 \pm 1.3 \mathrm{~h}$.

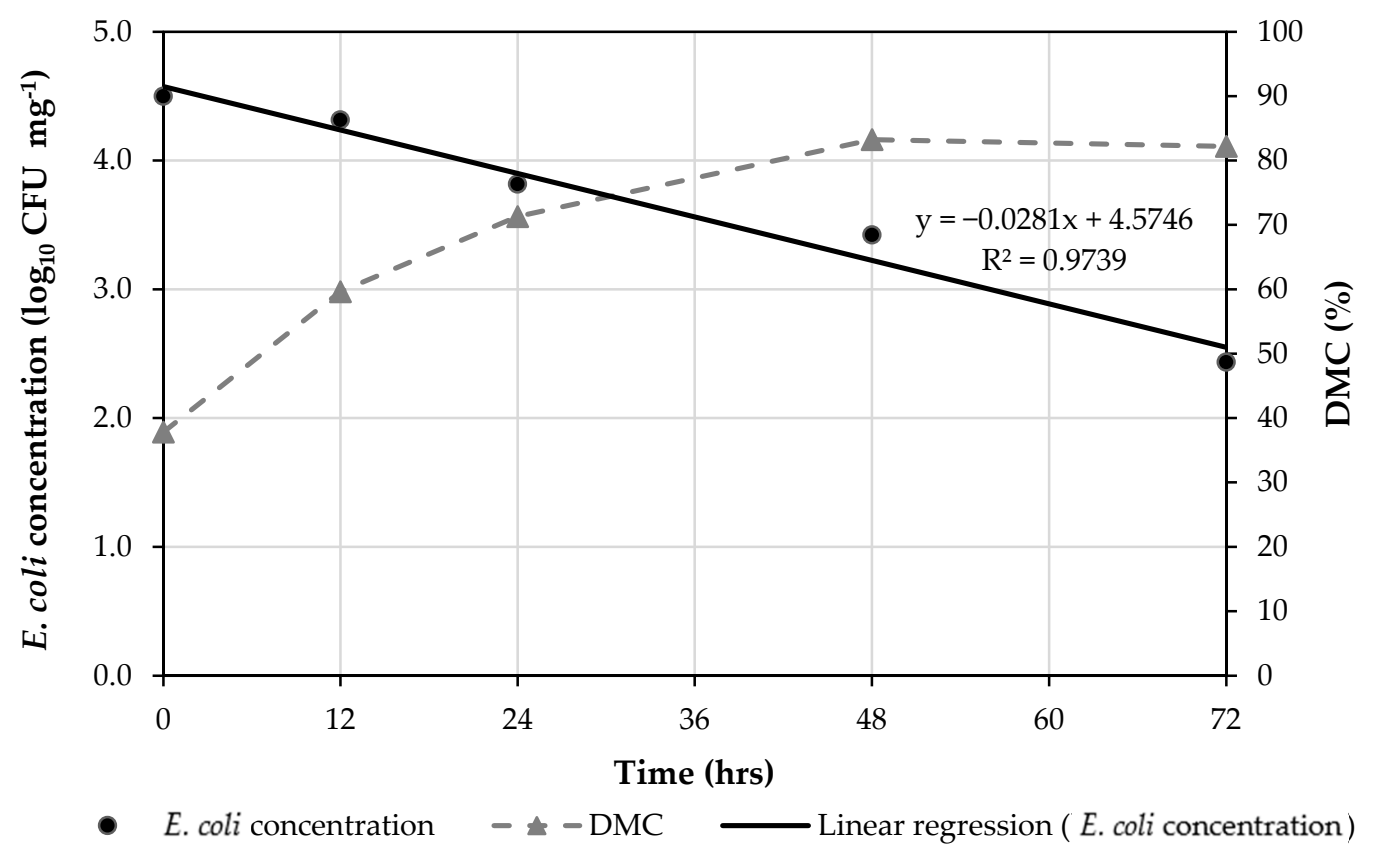

Figure 2. E. coli concentration and dry matter content (DMC) in poultry litter in a 72-h exposure under laboratory environmental condition $\left(20.5^{\circ} \mathrm{C}\right.$ and $\left.36 \%\right)$.

\subsection{Airborne E. coli Survivability}

The data collected from the first sampling and the second sampling to calculate the half-life time of E. coli were listed in the Table 3. As shown in Figure 1, most of the airborne E. coli were attached to dust particles larger than $2.1 \mu \mathrm{m}$, while only a small amount of total E. coli $(1.11 \%)$ attached to dust particles smaller than $2.1 \mu \mathrm{m}$. Therefore, when calculating the concentration of E. coli in dust, we only considered the concentration of dust particles larger than $2.1 \mu \mathrm{m}$. The DustTrak was able to monitor the dust particles having size range 
of 1.0-2.5 $\mu \mathrm{m}, 2.5-4.7 \mu \mathrm{m}, 4.7-10.0 \mu \mathrm{m}$ and larger than $10.0 \mu \mathrm{m}$. In this study, we assumed that the amount of dust particles larger than $2.1 \mu \mathrm{m}$ were equivalent to the amount of dust particles larger than $2.5 \mu \mathrm{m}$. The half-life time of the airborne E. coli based on dust with size $>2.5 \mu \mathrm{m}$ was $5.7 \pm 1.2 \mathrm{~min}$.

Table 3. Concentrations (Mean \pm SD) of dust particles with size larger than $2.5 \mu \mathrm{m}$, airborne E. coli and airborne E. coli-to-dust ratio during air sampling for survivability test of airborne E. coli. The 2nd sampling was performed $20 \mathrm{~min}$ after 1st sampling.

\begin{tabular}{ccc}
\hline Concentrations of Dust Particles and Airborne $E$. coli & 1st Sampling & 2nd Sampling \\
\hline Dust concentration with size $>2.5 \mu \mathrm{m}\left(\mathrm{mg} \mathrm{m}^{-3}\right)$ & $0.032 \pm 0.022$ & $0.016 \pm 0.012$ \\
Airborne $E$. coli concentration $\left(\log _{10} \mathrm{CFU} \mathrm{m}{ }^{-3}\right)$ & $7.1 \pm 0.7$ & $5.7 \pm 1.0$ \\
Airborne $E$. coli concentration carried by dust & $8.7 \pm 0.7$ & $7.5 \pm 0.9$ \\
concentration with size $>2.5 \mu \mathrm{m}\left(\log _{10}\right.$ CFU mg $\left.{ }^{-1}\right)$ & & \\
\hline
\end{tabular}

\subsection{Settled E. coli Survivability}

The survivability of settled E. coli was tested over $24 \mathrm{~h}$. In $24 \mathrm{~h}$, the concentration of settled $E$. coli declined from $3.7 \pm 0.1$ to $3.0 \pm 0.2 \log _{10} C F U \mathrm{mg}^{-1}$, yielding a half-life time of $9.6 \pm 1.6 \mathrm{~h}$ for settled E. coli.

\section{Discussion}

The aim of this study was to determine the survivability of airborne and settled E. coli in laboratory under dry aerosolization conditions. Survivability of E. coli was determined using half-life time as the indicator. To calculate the half-life time, concentrations of airborne E. coli and settled E. coli collected at two different time points after the dry aerosolization process were measured and compared. The survivability of E. coli in poultry litter that was used for dry aerosolization was also determined in a 72-h test under laboratory conditions $\left(20.5 \pm 0.3{ }^{\circ} \mathrm{C}\right.$ and $\left.36 \pm 4 \%\right)$. The results show that half-life times of airborne E. coli, settled E. coli, and E. coli in poultry litter were $5.7 \pm 1.2 \mathrm{~min}, 9.6 \pm 1.6 \mathrm{~h}$, and $15.9 \pm 1.3 \mathrm{~h}$, respectively.

In the airborne E. coli survivability test, the mean half-life time of the bacteria based on dust particles with size larger than $2.5 \mu \mathrm{m}$ was $5.7 \mathrm{~min}$. Hoeksma et al. [26] tested survivability of airborne $E$. coli under wet aerosolization conditions at $20{ }^{\circ} \mathrm{C}$ and $40-60 \%$. Their results showed that the half-life time of airborne E. coli under wet aerosolization conditions was about $2 \mathrm{~min}$, which was much shorter than the half-life time calculated in the present study. The difference between the half-life time of airborne E. coli under wet aerosolization conditions and dry aerosolization conditions could be explained by inactivation due to evaporation. After being aerosolized, the wet aerosols lost their water film due to evaporation and become sensitive to ambient influences [26]. Moreover, the difference in preparation of $E$. coli for aerosolization between the two studies could be another reason of the discrepancy in survivability results. In the current study, the E. coli were prepared in poultry litter and exposed at laboratory conditions over $48 \mathrm{~h}$ before aerosolization. As such, the E. coli had already gone through a dehydration process before aerosolization, which might leave only dehydration-resistant E. coli for following dry aerosolization. In the study by Hoeksma et al. [26], the E. coli were aerosolized immediately after preparation via the wet aerosolization. In addition, the autoclaving process of poultry litter could affect the quality of poultry litter and produce Maillard reaction product. The Maillard reaction products were proven to inhibit growth of bacteria [27]. However, the effect of the preparation procedure was not well-studied in the present study. Therefore, the effect still needs further investigation.

Survivability and transmission range of airborne E. coli may be affected by the size of particles that E. coli attached to. Zuo et al. [18] reported that the carrier particle size had a significant influence in the transmission and survivability of airborne virus. In their study, the authors mentioned that the survivability of virus attached to larger particles was much longer than that attached to smaller particles. The possible explanation presented by 
Zuo et al. [18] was the shielding effect. In other words, compared with viruses existing as a singlet or attaching to small particles, the virus attached to larger particles could be better protected from changes of ambient environment [28]. The concentration of $E$. coli should be proportional to the weight of airborne dust in the entire size spectrum, assuming a uniform mixture of E. coli and poultry litter. However, most of dust particles were smaller than $1.0 \mu \mathrm{m}$ (accounted for 57.60\%) and the majority of airborne E. coli were found to attach to dust particles larger than $2.1 \mu \mathrm{m}(98.89 \%)$. This contradiction could be explained again by the shielding effect. While E. coli attached to large particles could be protected from ambient influences, E. coli attached to small particles received less protection effect. It led to a rapid death of the E. coli attached to small particles during the aerosolization and sampling.

The half-life time of settled E. coli in this study was about $9.6 \mathrm{~h}$. Wilks et al. [16] tested the survivability of $E$. coli on metal surfaces at laboratory conditions at $20{ }^{\circ} \mathrm{C}$. In their study, the total number of viable $E$. coli dropped by 1 log after the first $3 \mathrm{~h}$, translating into an approximate $0.9 \mathrm{~h}$ half-life time. This discrepancy can be explained by differences in E. coli preparation methods, surfaces, and substrate (litter vs. liquid solution). As mentioned above, the E. coli preparation procedure in our study may affect the $E$. coli quality. Another possible explanation was metal surfaces used by Wilks et al. [16]. While the present study used regular plastic Petri dishes to collect settled E. coli, Wilks et al. [16] applied E. coli directly onto metal surfaces. This different material of surfaces could yield different survivability of E. coli. Ketkar et al. [29] indicated that stainless steel had antimicrobial effects. Further, different substrates (litter vs. liquid solution) used might have yielded different survivability of E. coli. While factors like $\mathrm{pH}$ and nutrient in poultry litter includes many affecting the survivability of bacteria [30,31], liquid solution used by Wilks et al. [16] for culturing E. coli was designed as a substrate for bacterial growth.

In the test of E. coli survivability in poultry litter, the half-life time was reported to be $15.9 \pm 1.3 \mathrm{~h}$. Compared with the half-life time of settled E. coli $(9.6 \mathrm{~h})$ and airborne E. coli (5.7 $\mathrm{min})$, the half-life time of E. coli in poultry litter was significantly longer. A possible explanation was that the E. coli in the poultry litter did not go through the aerosolization process which negatively affect the E. coli survivability [32]. While settled E. coli and airborne $E$. coli were aerosolized, E. coli in the poultry litter were not aerosolized. In addition, degree of sample exposure to the environment could affect the survivability of E. coli as well. Ruiz et al. [33] reported that bacterial survival was highly influenced by ambient influences. The airborne E. coli were scattered in the air and the settled E. coli were prepared in thin layers where E. coli were exposed to ambient environment and were more susceptible to microenvironment changes [34,35], as compared to E. coli in the poultry litter. In contrast, the $E$. coli in poultry litter existed in a chuck form could be more protected from microenvironmental effects [34-36].

\section{Conclusions}

The study determined the survivability of airborne, settled, and poultry litter E. coli under dry aerosolization conditions in laboratory. Based on the results, we conclude that (1) most E. coli could be carried by the dust particles with aerodynamic diameter $>2.1 \mu \mathrm{m}$, (2) the settled E. coli and the E. coli in poultry litter can survive much longer than airborne E. coli, and the mean half-life time was $5.7 \pm 1.2 \mathrm{~min}$ for airborne E. coli, $9.6 \pm 1.6 \mathrm{~h}$ for settled E. coli, and $15.9 \pm 1.3 \mathrm{~h}$ for E. coli in poultry litter.

Author Contributions: Conceptualization, X.D.N. and Y.Z.; methodology, X.D.N., Y.Z.; formal analysis, X.D.N.; investigation, X.D.N.; resources, Y.Z., J.L., J.D.E., J.L.P.; data curation, X.D.N.; writing-original draft preparation, X.D.N.; writing-review and editing, all co-authors; visualization, X.D.N.; supervision, Y.Z.; project administration, Y.Z.; funding acquisition, Y.Z., J.D.E., J.L.P. All authors have read and agreed to the published version of the manuscript.

Funding: Financial support for the study was provided by the USDA National Program (Project No.6064-13000-013-10S). 


\section{Institutional Review Board Statement: Not applicable.}

Informed Consent Statement: We have got the verbal permission from farmers to use the poultry litter for the study.

Acknowledgments: We appreciate the cooperation and assistance of the broiler grower in providing the broiler litter. This research was supported by the USDA National Institute of Food and Agriculture multistate project under accession number 1028091.

Conflicts of Interest: The authors declare no conflict of interest. The funders had no role in the design of the study; in the collection, analyses, or interpretation of data; in the writing of the manuscript, or in the decision to publish the results.

\section{References}

1. Poultry-Production and Value 2020 Summary; U.S. Department of Agriculture, National Agricultural Statistics Service (USDA, NASS): Washington, DC, USA, 2020.

2. Torremorell, M.; Alonso, C.; Davies, P.R.; Raynor, P.C.; Patnayak, D.; Torchetti, M.; McCluskey, B. Investigation into the airborne dissemination of H5N2 highly pathogenic avian influenza virus during the 2015 spring outbreaks in the Midwestern United States. Avian Dis. 2016, 60, 637-643. [CrossRef] [PubMed]

3. Saif, Y.; Barnes, H.; Glisson, J.; Fadly, A.; McDougald, L.; Swayne, D. Diseases of Poultry, 12th ed.; Blackwell Pub Professional: Ames, IA, USA, 2008; pp. 452-514.

4. Fancher, C.A.; Zhang, L.; Kiess, A.S.; Adhikari, P.A.; Dinh, T.T.; Sukumaran, A.T. Avian pathogenic Escherichia coli and Clostridium perfringens: Challenges in no antibiotics ever broiler production and potential solutions. Microorganisms 2020, 8, 1533. [CrossRef] [PubMed]

5. Zucker, B.A.; Trojan, S.; Müller, W. Airborne gram-negative bacterial flora in animal houses. J. Vet. Med. B Infect Dis. Vet. Public Health 2000, 47, 37-46. [CrossRef] [PubMed]

6. Munoz, L.; Pacheco, W.; Hauck, R.; Macklin, K. Evaluation of commercially manufactured animal feeds to determine presence of Salmonella, Escherichia coli, and Clostridium perfringens. J. Appl. Poult. Res. 2021, 30, 100142. [CrossRef]

7. Martin, S.A.; McCann, M.A.; Waltman, W.D., II. Microbiological survey of Georgia poultry litter. J. Appl. Poult. Res. 1998, 7, 90-98. [CrossRef]

8. Pitout, J.D. Extraintestinal Pathogenic Escherichia coli: A Combination of Virulence with Antibiotic Resistance. Front. Microbiol. 2012, 3, 9. [CrossRef]

9. Stęczny, K.; Kokoszyński, D. Effect of probiotic preparations (EM) on productive characteristics, carcass composition, and microbial contamination in a commercial broiler chicken farm. Anim. Biotechnol. 2021, 32, 758-765. [CrossRef]

10. McLeod, A.; Hovde Liland, K.; Haugen, J.E.; Sørheim, O.; Myhrer, K.S.; Holck, A.L. Chicken fillets subjected to UV-C and pulsed UV light: Reduction of pathogenic and spoilage bacteria, and changes in sensory quality. J. Food Saf. 2018, 38, e12421. [CrossRef]

11. Carpenter, G. Dust in livestock buildings-Review of some aspects. J. Agric. Eng. Res. 1986, 33, 227-241. [CrossRef]

12. Schulz, J.; Ruddat, I.; Hartung, J.; Hamscher, G.; Kemper, N.; Ewers, C. Antimicrobial-resistant Escherichia coli survived in dust samples for more than 20 years. Front. Microbiol. 2016, 7, 866. [CrossRef]

13. Sanz, S.; Olarte, C.; Hidalgo-Sanz, R.; Ruiz-Ripa, L.; Fernández-Fernández, R.; García-Vela, S.; Martínez-Álvarez, S.; Torres, C.J.A. Airborne Dissemination of Bacteria (Enterococci, Staphylococci and Enterobacteriaceae) in a Modern Broiler Farm and Its Environment. Animals 2021, 11, 1783. [CrossRef] [PubMed]

14. Zhao, Y.; Aarnink, A.; De Jong, M.; Groot Koerkamp, P.W.G. Airborne Microorganisms from Livestock Production Systems and Their Relation to Dust. Crit. Rev. Environ. Sci. Technol. 2014, 44, 1071-1128. [CrossRef] [PubMed]

15. Zhao, Y.; Richardson, B.; Takle, E.; Chai, L.; Schmitt, D.; Xin, H. Airborne transmission may have played a role in the spread of 2015 highly pathogenic avian influenza outbreaks in the United States. Sci. Rep. 2019, 9, 11755. [CrossRef] [PubMed]

16. Wilks, S.; Michels, H.; Keevil, C. The survival of Escherichia coli O157 on a range of metal surfaces. Int. J. Food Microbiol. 2005, 105, 445-454. [CrossRef]

17. Chan, W.L.; Chung, W.T.; Ng, T.W. Airborne Survival of Escherichia coli under Different Culture Conditions in Synthetic Wastewater. Int. J. Environ. Res. Public Health 2019, 16, 4745. [CrossRef]

18. Zuo, Z.; Kuehn, T.H.; Verma, H.; Kumar, S.; Goyal, S.M.; Appert, J.; Raynor, P.C.; Ge, S.; Pui, D.Y. Association of airborne virus infectivity and survivability with its carrier particle size. Aerosol Sci. Technol. 2013, 47, 373-382. [CrossRef]

19. Lighthart, B.; Shaffer, B.T. Increased airborne bacterial survival as a function of particle content and size. Aerosol Sci. Technol. 1997, 27, 439-446. [CrossRef]

20. Soliman, E.S.; Sallam, N.H.; Abouelhassan, E.M. Effectiveness of poultry litter amendments on bacterial survival and Eimeria oocyst sporulation. Vet. World 2018, 11, 1064-1073. [CrossRef]

21. Nguyen, X.D.; Zhao, Y.; Evans, J.D.; Lin, J.; Schneider, L.; Voy, B.; Hawkins, S.A.; Purswell, J.L. Evaluation of bioaerosol samplers for collecting airborne E. coli carried by dust particles from poultry litter. In Proceedings of the 2021 ASABE Annual International Virtual Meeting, Virtual, 12-16 July 2021; p. 1. 
22. Davis, M.; Morishita, T.Y. Relative ammonia concentrations, dust concentrations, and presence of Salmonella species and Escherichia coli inside and outside commercial layer facilities. Avian Dis. 2005, 49, 30-35. [CrossRef]

23. Crane, S.; Moore, J.; Grismer, M.; Miner, J. Bacterial pollution from agricultural sources: A review. Trans. ASAE 1983, 26, 858-866. [CrossRef]

24. Zhao, Y.; Aarnink, A.J.A.; Doornenbal, P.; Huynh, T.T.T.; Koerkamp, P.W.G.G.; de Jong, M.C.M.; Landman, W.J.M. Investigation of the efficiencies of bioaerosol samplers for collecting aerosolized bacteria using a fluorescent tracer. II: Sampling efficiency and half-life time. Aerosol Sci. Technol. 2011, 45, 432-442. [CrossRef]

25. Mubiru, D.; Coyne, M.S.; Grove, J.H. Escherichia coli pathogen O157: H7 does not survive longer in soil than a nonpathogenic fecal coliform. Agron. Notes 2000, 32, 2.

26. Hoeksma, P.; Aarnink, A.J.A.; Ogink, N.W.M. Effect of Temperature and Relative Humidity on the Survival of Airborne Bacteria = Effect van Temperatuur en Relatieve Luchtvochtig-Heid op de Overleving van Bacteriën in de Lucht; 1570-8616; Wageningen UR Livestock Research: Wageningen, The Netherlands, 2015.

27. Bhattacharjee, M.K.; Sugawara, K.; Ayandeji, O.T. Microwave sterilization of growth medium alleviates inhibition of Aggregatibacter actinomycetemcomitans by Maillard reaction products. J. Microbiol. Methods 2009, 78, 227-230. [CrossRef]

28. Woo, M.-H.; Grippin, A.; Anwar, D.; Smith, T.; Wu, C.-Y.; Wander, J.D. Effects of relative humidity and spraying medium on UV decontamination of filters loaded with viral aerosols. Appl. Environ. Microbiol. 2012, 78, 5781-5787. [CrossRef] [PubMed]

29. Ketkar, G.N.; Malaiappan, S.; Muralidharan, N. Comparative Evaluation of Inherent Antimicrobial Properties and Bacterial Surface Adherence between Copper and Stainless Steel Suction Tube. J. Pharm. Res. Int. 2020, 32, 149-156. [CrossRef]

30. Terzich, M.; Pope, M.J.; Cherry, T.E.; Hollinger, J. Survey of pathogens in poultry litter in the United States. J. Appl. Poult. Res. 2000, 9, 287-291. [CrossRef]

31. Neher, D.; Cutler, A.; Weicht, T.; Sharma, M.; Millner, P. Composts of poultry litter or dairy manure differentially affect survival of enteric bacteria in fields with spinach. J. Appl. Microbiol. 2019, 126, 1910-1922. [CrossRef]

32. Zhen, H.; Han, T.; Fennell, D.E.; Mainelis, G. A systematic comparison of four bioaerosol generators: Affect on culturability and cell membrane integrity when aerosolizing Escherichia coli bacteria. J. Aerosol Sci. 2014, 70, 67-79. [CrossRef]

33. Ruiz-Gil, T.; Acuna, J.J.; Fujiyoshi, S.; Tanaka, D.; Noda, J.; Maruyama, F.; Jorquera, M.A. Airborne bacterial communities of outdoor environments and their associated influencing factors. Environ. Int. 2020, 145, 106156. [CrossRef]

34. Tuson, H.H.; Weibel, D.B. Bacteria-surface interactions. Soft Matter 2013, 9, 4368-4380. [CrossRef]

35. Fernandez, M.O.; Thomas, R.J.; Garton, N.J.; Hudson, A.; Haddrell, A.; Reid, J.P. Assessing the airborne survival of bacteria in populations of aerosol droplets with a novel technology. J. R. Soc. Interface 2019, 16, 20180779. [CrossRef] [PubMed]

36. Soupir, M.; Mostaghimi, S.; Yagow, E.; Hagedorn, C.; Vaughan, D. Transport of fecal bacteria from poultry litter and cattle manures applied to pastureland. Water Air Soil Pollut. 2006, 169, 125-136. [CrossRef] 